\title{
ОСОБЛИВОСТІ КОНТЕКСТІВ ЗМІСТУ СОЦІАЛЬНИХ УЯВЛЕНЬ СУЧАСНОЇ МОЛОДІ ПРО “СПРАВЕДЛИВІСТЬ- НЕСПРАВЕДЛИВІСТЬ”
}

\begin{abstract}
Визначаються історичні витоки концептуалізації феномену “справедливість” як об'єктивної властивості соціальної системи 3 погляду іiї ставлення до особистості. Справедливість розглядається як одна 3 найважливіших соціальних цінностей, що $є$ критерієм оцінювання взаємодії та відіграє суттєву роль у найрізноманітніших відносинах від особистісних до суспільно-політичних. Зазначається, що зміст ідеї справедливості, тобто певних уявлень, які існують у суспільній свідомості, є історично і культурно обумовленим. Обѓрунтовується динамічний, а тому відносний характер уявлень про справедливість. Виокремлюються функції уявлень про справедливість: оцінювання, контролю, регуляції поведінки, збереження цілісності соціальної групи, впливу на емоційний стан і процеси соціального пізнання, а також принципи: балансу, дотримання норм і домовленостей, рівності, третейського судді, суб'єктивності. Наводяться дані емпіричного дослідження, у ході якого з'ясовувалося буденне розуміння сучасною молоддю справедливості-несправедливості, визначилися контексти застосування поняття “справедливість”, аналізувалось оцінювання подій з погляду справедливості та уявлень про можливі стратегії досягнення або відновлення справедливості в різних сферах життєдіяльності молоді.

Ключові слова: справедливість, принципи справедливості, уявлення про справедливість, контексти понять “справедливістьнесправедливість”, функції справедливості, стратегії досягнення або відновлення справедливості.
\end{abstract}

Проблема. Концептуалізація феномену “справедливість” бере свій початок у працях античних філософів і знаходить своє продовження в доробку видатних філософів доби Відродження та Нового часу. I хоч у різні часи розуміння суті і ставлення до справедливості інколи кардинально відрізнялися (від розуміння справедливості як соціальної цінності в працях Арістотеля до заперечення справедливості через брак загальних уявлень про справедливість у лідера лібертаризму Фрідріха фон Гайєка), справедливість завжди перебувала в полі зору дослідників, що працюють у різних галузях та сферах наукового знання: у правовій (R. А. Anderson, A. L. Otto; О. О. Гулевич, О. О. Голинчик та ін.) й економічній (J. B. Fuller, K. Hester; M. Wenzel та ін.); політичній (T. S. Kershaw, S. Alexander; W. R. Louis, J. M. Duck, D. J. Terry, A. Schuller, R. N. Lalonde та ін.) й організаційній (J. A. Colquitt, D. E. Conlon, M. J. Wesson, C. O. Porter та ін.). 
Дослідження феномена “справедливість” широко представлені в працях зарубіжних соціальних психологів. Так, вивченню характеру, місця та ролі справедливості в буденній свідомості присвячено праці Ж. Піаже, Л. Колберга, О. М. Здравомислової, Л. І. Анциферової та ін. Низка авторів зосереджує свою увагу на дослідженні індивідуальних відмінностей в уявленнях про справедливість (Z. Rubin, L. A. Peplau; M. J. Lerner, D. T. Miller; M. J. Lerner; M. J. Lerner, L. Goldberg, P. Tetlock; M. Schmitt, M. Gollwitzer, J. Maes, D. Arbach та ін.) і на стратегіях відновлення справедливості, а також на зв'язках справедливості 3 різними соціальними феноменами (M. Deutch; M. Lemer; R. Folger; J. Greenberg, R. Gohen; S. Brams; K. Leung, W. Stephan; G. Mikula, M. Wenzel; H. Triandis; Дж. Мацумото та ін.).

Особливої популярності серед психологів, на початку 1970-х років, за J. S. Adams, набула проблематика справедливості взаємодії. Так, у працях J. Thibaut, H. H. Kelley було сформульовано основні теоретичні принципи та запропоновано центральні поняття теорій справедливого обміну: результати взаємодії, затрати, дистрибутивна справедливість.

Принцип дистрибутивної справедливості визнано основною нормою соціальної взаємодії. Однак недостатній ступінь операціоналізованості основних категорій, а також наголос на схемах діадичної взаємодії викликали у дослідників певну невдоволеність. У результаті 3'являються нові концепції, які дають змогу пояснити не лише діадичні, а й інші види соціальної взаємодії (M. Patche, J. S. Adams та ін.).

$\mathrm{У}$ вітчизняній соціальній психології започатковано принципово новий підхід до вивчення феномена справедливості - 3 позицій аналізу iii ціннісних (М. М. Слюсаревський) і суб’єктних (В. О. Татенко) характеристик.

На основі аналізу наукових джерел можна зробити висновок, що справедливість належить до найважливіших соціальних цінностей, $є$ одним 3 головних критеріїв оцінювання взаємодії та відіграє суттєву роль у найрізноманітніших відносинах - від особистісних до суспільно-політичних. Уявлення про справедливість формується в процесі соціальної взаємодії, взаємообміну діяльністю та ії результатами. Люди керуються своїми уявленнями про справедливість, коли оцінюють інших i взаємодіють 3 ними. Поняття “справедливість" також пов'язане з усвідомленням міри та критеріїв зіставлення дій одних людей щодо інших або державних інституції щодо різних категорій громадян.

У найбільш загальному вигляді справедливість можна визначити як об 'єктивну властивість соиіальної системи з погляду ї̈ ставлення до особистості. Відображенням цієї властивості є усвідомлення, почуття справедливості, яке характеризується задоволеністю або неза- 
доволеністю тих чи інших потреб, ставлень, відносин і т. ін. Коли йдеться про справедливість, то завжди постає питання про відповідність конкретних суспільних норм загальновизнаним соціальним принципам, i, в цьому розумінні, справедливість виконує регулятивну функцію.

Загалом поведінка соціального суб'єкта спрямована на утвердження такої форми суспільного життя, яка відповідає його інтересам та потребам. Саме залежно від оцінювання задоволеностінезадоволеності своїх інтересів та потреб, стосунків, які при цьому складаються, вибудовується поведінка суб'єкта. Міра відповідності та iii характер залежать від конкретних історичних, соціальноекономічних та суспільних умов. У цьому сенсі можна говорити про відносний характер справедливості, а враховуючи те, що кожне суспільство розвивається, - про динамізм ідеї справедливості. Можна з упевненістю стверджувати, що зміст ідеї справедливості, тобто певних уявлень, які існують у суспільній свідомості, не $\epsilon$ абсолютним для всіх часів та всіх суспільств.

Теоретичний аналіз наукових джерел дав змогу виділити низку функцій уявлень про справедливість, а саме функції оцінювання та контролю, регуляції поведінки, збереження цілісності соціальної групи, впливу на емоційний стан та на процеси соціального пізнання. Чи не найважливішою функцією уявлень про справедливість є регулятивна функція. Ідея про регулятивність цих уявлень належить Дж. Адамсу, Г. Левенталю, І. Уолстеру. Так, справедливість у спілкуванні вони зводять до традиційної послідовності: оцінювання справедливості взаємодії актуалізує атитюди учасників взаємодії, які відтак впливають на наміри та реальну поведінку.

Подальший аналіз досліджень уявлень про справедливість і несправедливість показав, що ці уявлення у представників різних соціальних груп істотно відрізняються та мають певні культурні особливості (К. Лейнг, В. Дж. Стефан; Major, Adams; Chin). Таким чином, можна зробити висновок, що су'єктом уявлень про справедливість $\epsilon$ соціальна група, яка виробляє, конструює ці уявлення відповідно до пріоритетних для неї цінностей, норм, звичаїв та традицій.

Мета намого емпіричного дослідження:

1) з'ясувати зміст буденного розуміння сучасною молоддю справедливості-несправедливості;

2) визначити контексти застосування поняття “справедливість" та сфери оцінювання подій з погляду справедливості;

3) виявити уявлення про можливі стратегії досягнення або відновлення справедливості в різних сферах життєдіяльності молоді.

В емпіричному дослідженні взяли участь студенти факультетів гуманітарного профілю (108 осіб) та юридичного факультету (42 осо- 
би) віком від 18 до 21 року. Серед респондентів були 91 жінка і 59 чоловіків.

Щоб з'ясувати загальну структуру уявлень про справедливість, ми скористалися методом фокус-групи (52 учасники). Завдяки отриманим під час проведення фокус-груп результатам було проаналізовано раціональне осмислення поняття “справедливість”. Для виявлення емоційного, оціночного ставлення та невідрефлексованих компонентів соціальних уявлень про справедливість використовувався метод довільних асоціацій (98 учасників).

У сформованих групах дослідження проводилося відповідно до топік-гайду, який охоплював кілька етапів: 1) знайомство, оприлюднення плану роботи, мотивування; 2) з'ясування основних компонентів розуміння, що таке справедливість-несправедливість; 3) виокремлення контекстів оцінювання справедливих-несправедливих подій (метод довільних асоціацій). Завершувалася робота дискусією про реальну наявність справедливості в різних сферах життя сучасної молоді, про можливість та шляхи досягнення або відновлення справедливості в сучасній Україні. Робота у фокус-групах тривала дві години, при цьому проводився аудіозапис.

Далі здійснювався якісний аналіз результатів фокус-груп. Отримані за методикою довільних асоціацій дані сортувалися за загальною ознакою, підраховувалися частота згадувань та відповідний відсоток респондентів. Проводячи аналіз, ми ставили завдання не лише виявити емоційний компонент соціальних уявлень, а й окреслити семантичний простір, до якого належить це поняття.

У ході аналізу аудіозаписів виділялися ключові моменти в розумінні справедливості-несправедливості, щодо яких група мала узгоджену думку. За результатами такого аналізу було сформовано узагальнене, буденне визначення справедливості і несправедливості, а також певні принципи справедливості. Аналізувались оцінки можливості досягнення (відновлення) справедливості взагалі та в Україні зокрема. Визначалися контексти, у яких респонденти застосовували поняття “справедливість”, давалася оцінка справедливим і несправедливим подіям. 
За результатами дискусії було сформульовано основні принщипи справедливості:

a) принцип балансу - один із головних елементів визначення справедливості. Виявом балансу може слугувати принцип відповідності у стосунках. При цьому справедливість розуміється як поновлення порушеного балансу, тобто поновлення правди;

б) принцип дотримання норм і домовленостей. Наголошує, що справедливість - це дотримання, а несправедливість - порушення особою норм і правил, які поділяє група;

в) принцип рівності. Передбачає, що справедливість - це дотримання, а несправедливість - порушення рівності прав і можливостей;

г) принцип третейського судді. Полягає в тому, що справедливість може бути реалізована чи відновлена лише незацікавленою особою;

д) принцип суб'єктивності розуміння. Констатує, що оцінки щодо справедливості завжди суб' єктивні.

Значну увагу під час дослідження було приділено способам відновлення справедливості. Аналіз показав, що найбільш популярними серед респондентів були такі судження щодо досягнення справедливості:

- справедливість є недосяжною взагалі;

- справедливість $\epsilon$ недосяжною в нашій країні (незахищеність, корумпованість судової влади, політична корупція тощо);

- справедливості можна досягнути лише в стосунках з близькими людьми;

- справедливість досягається за допомогою хабара (лікарю, поліцейському, судді, викладачеві, роботодавцю).

Переважна більшість респондентів як спосіб відновлення справедливості найчастіше називала покарання винного в судовому порядку. Однак лише незначна частка респондентів (близько 4\%) вірить у можливість відновлення справедливості в такий спосіб. Ще одним способом - і більш дієвим, на думку респондентів, $-\epsilon$ самостійне відновлення справедливості через протестні акції (при цьому наводилися конкретні випадки відновлення справедливості: заборона будівництва, знесення парканів біля водойм тощо), а також громадський контроль та боротьба 3 корупцією в органах державної влади і судах. Окремо респонденти виділяли справедливість у політико-правовій сфері, якої можна досягнути, на їхню думку, завдяки активності громадян. Прикметно, що лише близько $2 \%$ респондентів так чи інакше виявляли свою громадянську позицію. Разом 3 тим майже $70 \%$ опитаних були готові долучитися до участі в громадських акціях по відновленню справедливості. 
Згідно 3 результатами, одержаними за методикою довільних асоціацій найбільш згадуваними асоціаціями зі словом “справедливість” були: змагання, закон, міраж, боротьба, обман, дружба, сім'я, мрія, зброя, розчарування, суд, республіка, революція, сльози, сила, правда, рівність, порядність, повага, честь, совість, доброта. А зі словом “несправедливість” асоціювалися обман, злочин, нерівність, влада, зрада, зло, жорстокість, олігархи, суд, поліція, нерозуміння, беззаконня, насилля, реальність, підлість, беззахисність, закон, держава, політика, упередженість, суб'єктивність, помста, ворожнеча, байдужість, шахрайство, нечесність, війна, агресія, покарання, в'язниця.

На основі частотного аналізу асоціацій було виділено групи зі спільними ознаками. Це групи асоціацій з поняттями “справедливість” (рис.1) і “несправедливість” (рис. 2).

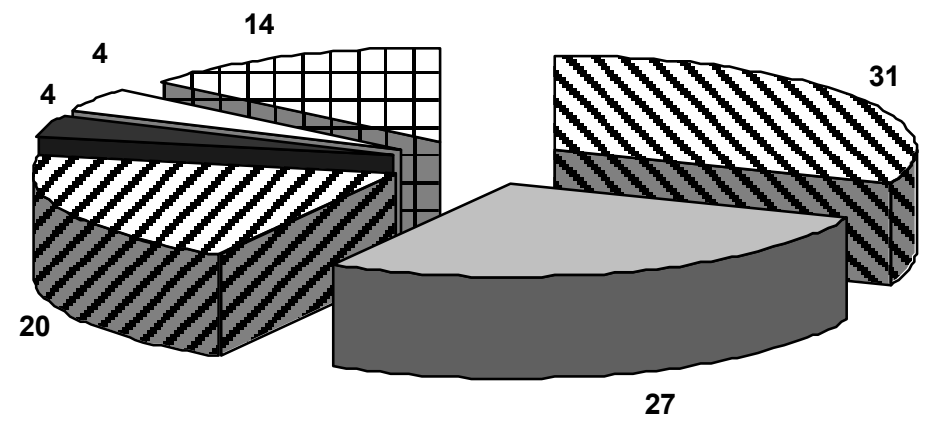

\begin{tabular}{|c|c|}
\hline $\begin{array}{l}\text { особистісний } \\
\text { міжособистісний } \\
\text { діловий (навчальний) }\end{array}$ & $\begin{array}{l}\text { 口 політико-правовий } \\
\square \text { філософссько-релігійний } \\
\square \text { емоційний }\end{array}$ \\
\hline
\end{tabular}

Рuc. 1. Частка згадувань асоціацій $з$ поняттям “справедливість” у різних контекстах 
Як видно 3 рис. 1, найбільша частка асоціацій з поняттям “справедливість" припадає на особистісний контекст. Під ним розуміють позитивні якості і риси особистості - чесність, доброту, вірність, гуманність, порядність, гідність, моральність і т. ін. Друге місце, дещо неочікувано, посів політико-правовий контекст - рівність, свобода, влада, революція, закон, суд, право, демократія, республіка, покарання тощо. Наступними за частотою згадувань асоціацій виявилися міжособистісний (ставлення до інших), а це розуміння, повага, дружба, сім'я, толерантність, та емоційний (щастя, радість, любов) контексти. П’яте і шосте місця (лише по 4\%) посіли філософсько-релігійний (істина, віра, людство, доля, Бог) та діловий або навчальний (нагорода, праця, змагання, екзамен) контексти.

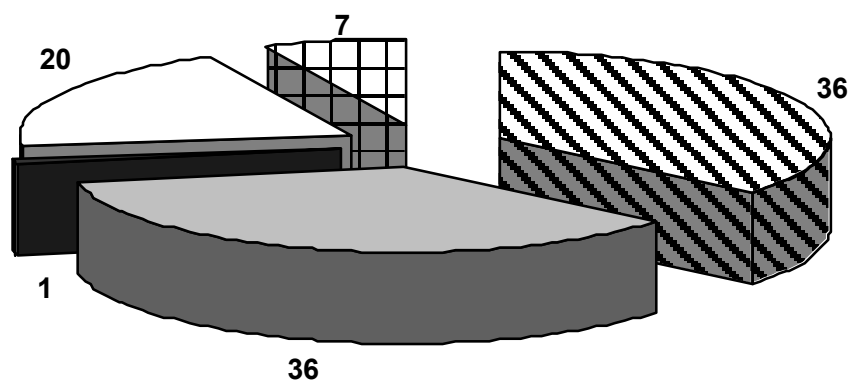

\begin{tabular}{ll}
\hline $\begin{array}{l}\mathbf{\Xi} \text { особистісний } \\
\text { фрілософсько-релігійний } \\
\text { घ емоційний }\end{array}$ & $\square$ політико-правовий \\
\hline
\end{tabular}

Рuc. 2. Частка згадувань асоціацій з поняттям “несправедливість” у різних контекстах

Як і у випадку асоціацій з поняттям “справедливість”, найбільша частка згадувань асоціацій з поняттям “несправедливість” припадає на міжособистісний і політико-правовий контекст. Наведемо відтак приклади груп асоціацій з поняттям “несправедливість":

1) міжособистісний контекст (ставлення до іншого): образа, обман, неправда, провина, біль, нерозуміння, підлість, ворожнеча, шкода, непорядність, приниження, байдужість, помста, зрада;

2) політико-правовий контекст: суд, влада, уряд, поліція, беззаконня, тиранія, хабарництво, кумівство, олігархія, грабіж, в'язниця, 
покарання, війна, нерівність, зрада, беззахисність, шахрайство, маніпулювання, вибори, уряд, дискримінація, пригноблення;

3) діловий (навчальний) контекст: екзамен, шпаргалка, заробітна плата, блат;

4) філософсько-релігійний контекст: зло, доля, розплата;

5) емоційний контекст: відчай, горе, злість.

Висновки:

1. Буденні уявлення про “справедливість" і “несправедливість” містять спільні компоненти: досягнення (порушення) балансу як характеристика справедливого (несправедливого) наслідку; дотримання (порушення) значущих норм, рівність прав і можливостей; уникнення суб'єктивності при прийнятті рішень.

2. Головними елементами уявлень сучасної молоді про “справедливість" i “несправедливість" $є$ принципи досягнення балансу і відповідності нормам.

3. Уявлення про “справедливість" і “несправедливість” відрізняються за такими параметрами: а) емоційна складова соціальних уявлень про несправедливість $є$ більш місткою, ніж уявлень про справедливість; б) уявлення про несправедливість мають пріоритет над уявленнями про справедливість (це виявляється в оцінці справедливості як недосяжної в усіх контекстах, окрім політико-правового, де справедливості можна досягнути за умови активної громадянської позиціі).

4. Усупереч поширеній думці про те, що молодь не цікавиться політико-правовими проблемами, проведене нами дослідження показало, що політико-правовий контекст уявлень про справедливість займає значне місце у змісті їі соціальних уявлень.

\section{Лimepamypa}

1. Гулевич О. А. Социальная психология справедливости: Бизнес, политика, юриспруденция / О. А. Гулевич. - М. : Аспект Пресс, 2007. - 254 с.

2. Сіверс 3. Ф. Уявлення про справедливість як складова політико-правової свідомості особистості / З. Ф. Сіверс // Юридична психологія. - 2015. № $1 .-$ C. $32-42$.

3. Соснина Л. М. Тенденции исследования справедливости в зарубежной социальной психологии / Л. М. Соснина // Психологический журнал. 2006. - T. 27, № 5. - С. 40-50. 


\section{References}

1. Gulevich, O. A. (2007). Sotsialnaya psikhologiya spravedlivosti: Biznes, politi$k a$, yurisprudentsiya [Social psychology of justice: Business, Politics, Jurisprudence]. Moscow: Aspekt Press Publ. (rus).

2. Sivers, Z. F. (2015). Uiavlennia pro spravedlyvist yak skladova politykopravovoi svidomosti osobystosti [Ideas about justice as constituent of politicallegal consciousness of personality]. Yurydychna psykholohiia [Legal psychology], 1, 32-42 (ukr).

3. Sosnina, L. M. (2006). Tendentsii issledovaniya spravedlivosti v zarubezhnoy sotsialnoy psikhologii [Trends in justice study in foreign social psychology]. Psikhologicheskiy zhurnal [Psychological journal], 5, 40-50 (rus).

\section{Sivers Z. F. Features of meaning contexts on social ideas of modern youth about "Justice-injustice"}

The historical origins of conceptualization of "justice" phenomenon as an objective feature of social system from the point of view of its atittudes towards personality are determined. Justice is considered as one of the most important social values, which is a criterion of interaction evaluating and plays an essential role in a wide variety of relationships - from personal to social and political ones. It is noted that the content of idea about justice, namely, certain ideas that exist in public consciousness, are historically and culturally determined. Dynamic and so relative nature of ideas about justice is substantiated. The functions of representations about justice are singled out: evaluation, control, regulation of behavior, saving of the social group integrity, influence on the emotional state and processes of social cognition, as well as principles: balance; adhere to the norms and agreements, equality, arbitrator, subjectivity. It was represented the data of the empirical research, in which the daily understanding of the modern youth about justice-injustice is clarified, and the contexts of useing the concept of "justice" are determined. The evaluation of events from the point of view of justice and ideas about possible strategies for achieving or restoring justice in various spheres of youth activity is analyzed.

Key words: justice, principles of justice, ideas about justice, contexts of concepts "justice-injustice", functions of justice, strategies for achieving or restoring justice. 
